\title{
Analysis of Risk Factors That Influence Coping Strategy of Mothers Who Have Children with Autism in Arogya Mitra Acupuncture
}

\author{
$1^{\text {st }}$ Suyami \\ Department of Nursing \\ STIKES Muhammadiyah Klaten \\ Klaten, Central Java, Indonesia, Ir. \\ Soekarno Street, Km.1, Buntalan, \\ Central Klaten, Klaten, Central Java, \\ Indonesia \\ suyami@stikesmukla.ac.id \\ $4^{\text {th }}$ A D Sulistyowati \\ Department of Nursing \\ STIKES Muhammadiyah Klaten \\ Klaten, Central Java, Indonesia, Ir. \\ Soekarno Street, Km.1, Buntalan, \\ Central Klaten, Klaten, Central Java, \\ Indonesia
}

\begin{abstract}
Parents especially mothers who have autistic children have their own stress and need coping strategies to overcome them. The purpose of this study was to determine the risk factors that influence coping strategies of mothers who have children with autism in Arogya Mitra Acupuncture Klaten. We used a non-experimental quantitative design with a cross-sectional survey design. The results of this study indicated that no relationship between age and mothers coping strategies because with $p=0.921$ ( $p>$ $0.05)$. We found no relationship between economic status and mothers coping strategies with $p=0.278$ and multivariate analysis resulted $0.111(p>0.05)$. In addition, we found no relationship between education level with mothers coping strategy with $p=0.470(p>0.05)$. Moreover, we found a relationship between family support and mothers coping strategies with $p=0.011$ and multivariate analysis resulted $0.019(p<0.05)$. The conclusion of this study are the risk factors that influence coping strategies namely family support, meanwhile others risk factors do not affect coping strategies namely age, education level, economic status.
\end{abstract}

Keywords-Risk Factor, Children, Autism

\section{INTRODUCTION}

The prevalence of autism is increasing worldwide. Until before 2000, the prevalence of autism is 2-5 to 15 20 per 1.000 births, $1-2$ per 1.000 world population. The Autism Society of America (ASA) data in 2000 finds autism occured in 60 per 10.000 livebirths, with a total ratio 1: 250 of the population. Meanwhile, the data of Centers for Disease Control and Prevention (CDC), United States of America (USA) in 2001 was 1 in 150 population and in several regions of USA/United Kingdom (UK) is among 100 population. In 2012, CDC found that 1:88 children had autism, and in 2014 there is an increase by $30 \%$, become $1.5 \%$ or $1: 68$ of children in the USA had autism, whereas in Indonesia Central
Statistics Agency (BPS) there were no definitive data on the number of autism yet. Indonesia's population reach 237.5 million with a population growth rate of $1.14 \%$. Furthermore, it is estimated that Autism Spectrum Disorder (ASD) sufferers in Indonesia are 2.4 million people with the addition of 500 new cases/year [1].

Cases of children with autism spectrum disorders are increasing every day. The Ministry of Health's Director of Mental Health Development, Diah Setia, said there were an estimated 112.000 children in Indonesia with autism, ranging in age from around 5-19 years old. Autism spectrum disorders are developmental disorders that cause the child (from birth or several months after birth) to experience delays and deviations from normal behavioral patterns in the area of social relations and interactions, language and communication, and other activities. Families with ASD children are required to adapt to the circumstances, needs, and special handling for it which are quite complicated. Parents of children with ASD are reported to have higher levels of stress than parents with other children with disabilities such as down syndrome. As for mothers, the effects resulting from having children with ASD tend to be greater. A mother with ASD child will face many challenges that are difficult to overcome [2].

Autism Spectrum Disorder (ASD) refers to a series of conditions that are characterized by some degree of disruption of social behavior, communication and language, and various narrow interests and activities that are unique to the individual and carried out repeatedly. ASD starts in childhood and tends to last into adolescence and adulthood. In most cases, the condition is clearly visible during the first 5 years of life. Individuals with ASD often experience other conditions that occur together, including epilepsy, depression, anxiety and Attention Deficit Hyperactivity Disorder (ADHD). The 
level of intellectual function in individuals with ASD varies greatly, ranging from deep disturbances to higher levels [3].

Children with special needs are called children with Autistic Spectrum Disorders (ASD) or more commonly called children with autism. Individuals with ASD are one of the five types of Pervasive Development Disorder, not hearing or looking at the eyes when invited to communicate is an identifier in addition to a variety of other symptoms, such as communication that is difficult to understand, unstable emotions and unusual behavior [4]. Aeni et al found that this disorder was more frequent in high socio-economic status, but this might be influenced by bias, because in the last 25 years there was an increase in cases in low socio-economic groups. This discovery may be due to increase awareness of this disorder and increase health facilities for poor families [5]. Research conducted by Gona, Newton, Rimba in 2016 explains that coping strategies applied by parents target the physical health of the child and the psychological wellbeing of the parent [6].

Autism or Autism Spectrum Disorder is a variety of conditions characterized by several levels of disturbed social behavior, communication and language, and various narrow interests and activities that are unique to the individual and are carried out repeatedly. The majority of mothers stress phenomena are higher than fathers stress [7]. Parents who have autistic children tend to feel more stressed and depressed because they have an important role in handling and caring for their children [8]. Autism is still a nightmare for most parents. Parents with autism children can be very stressed when dealing with hyperactive, aggressive and passive child behavior. Stress experienced by parents of children with autism will affect the ability of parents in the role of childcare, especially in relation to coping strategies that have been faced with children's problems. Parent participation is very important for success in socializing with children with autism in the general population [9]. The results of the study of Astuti et al showed that stress frequency of parents who have autistic children mostly experience stress $(86.7 \%)$ and the rest feel normal (13.3\%). There is a correlation between coping strategies with stress of parents of autistic children, so coping strategies are one of the risk factors. This means that coping strategies have a risk of 4.667 times the stress experienced by mothers who have autistic children. It is recommended that parents pay attention and accept the condition of their children [10]. The results from Nisa's research showed that parents who have autistic children experience a lack of understanding of autistic children, experience physical fatigue and economic difficulties. Parents face problems that arise in various ways, there are forms of coping that were successfully revealed in this study, including coping based on emotions, namely patience, coping based on problems that parents bring to the doctor to be treated, send autistic children to special education, learn from the behavior of autistic children teach and model daily activities for autistic children, find work and rest when sick. Researchers can also uncover the form of religious coping, namely tawakal. Optimal or not the chosen coping is influenced by age, gender, economic status, level of education and environmental connections [8].

\section{METHOD}

The design of this study used a non-experimental quantitative design with a cross-sectional survey design [11]. A study to determine the dynamics of the correlation between risk factors and effects, by way of approach, observation or data collection at a time (point time approach). That is, each research subject was only observed once and measurements were made on the character status or subject variables at the time of examination.

This research was conducted on 24 June $2019-8$ July 2019 with 60 respondents who had autistic children. This research was conducted at Arogya Mitra Acupuncture Klaten located in Hamlet Ngemplak, Kalikotes, Klaten, Central Java. To ensure the patience of Arogya Mitra Acupuncture Klaten specifically also provides a place to stay for children and families who come from outside the city.

\section{RESULT}

TABEL 1. DISTRIBUTION OF RESPONDENT FREQUENCIES BY AGE, ECONOMIC STATUS, EDUCATIONAL LEVEL, FAMILY SUPPORT AND COPING STRATEGIES OF MOTHERS WHO HAD AUTISTIC CHILDREN IN AROGYA MITRA ACUPUNCTURE KLATEN $(\mathrm{N}=60)$

\begin{tabular}{|l|l|l|}
\hline Variables & Frequency (f) & Percentage (\%) \\
\hline Age & & \\
\hline $36-45$ Late adulthood & 35 & 58,3 \\
\hline $46-55$ Early elderly & 25 & 41,7 \\
\hline Economy status & & \\
\hline Less than minimum regional wage & 25 & 41,7 \\
\hline More than minimum regional wage & 35 & 58,3 \\
\hline Education level & & \\
\hline High school & 40 & 66,7 \\
\hline Higher education & 20 & 33,3 \\
\hline Family support & & \\
\hline Poor & 20 & 33,3 \\
\hline Good & 40 & 66,7 \\
\hline Coping strategy & & \\
\hline
\end{tabular}




\begin{tabular}{|l|l|l|}
\hline Poor & 16 & 26,7 \\
\hline Good & 44 & 73,3 \\
\hline Total & 60 & 100,0 \\
\hline
\end{tabular}

Based on Table 1, it showed that the respondents who had autistic children in Arogya Mitra Acupuncture Klaten most are the age of late adulthood $35-45$ years as many as 35 respondents $(58.3 \%)$. The economic status of respondents mostly those who earn more than minimum regional wage of Klaten regency, namely 35 respondents $(58.3 \%)$. The education level of respondents mostly those with junior or senior high school graduate as many as 40 respondents $(66.7 \%)$. The family support of respondents mostly had good family support as many as 40 respondents $(66.7 \%)$. Coping strategy of respondents mostly had a good coping strategy as many as 44 respondents $(73.3 \%)$.

\begin{tabular}{|c|c|c|c|c|c|c|c|}
\hline \multirow[t]{3}{*}{ Variables } & \multicolumn{4}{|c|}{ Coping Strategy } & \multicolumn{2}{|c|}{ Total } & \multirow[t]{3}{*}{ P-Value } \\
\hline & \multicolumn{2}{|c|}{ Poor } & \multicolumn{2}{|c|}{ Good } & \multirow[t]{2}{*}{$\mathrm{f}$} & \multirow[t]{2}{*}{$\%$} & \\
\hline & $\mathrm{f}$ & $\%$ & $\mathrm{~F}$ & $\%$ & & & \\
\hline Age & & & & & & & \\
\hline 36-45 Late adulthood & 10 & 28,6 & 25 & 27,4 & 35 & 100,0 & 0,921 \\
\hline \multirow[t]{3}{*}{ Variables } & \multicolumn{4}{|c|}{ Coping strategy } & \multicolumn{2}{|c|}{ Total } & $\mathrm{P}$-value \\
\hline & \multicolumn{2}{|c|}{ Poor } & \multicolumn{2}{|c|}{ Good } & $\mathrm{f}$ & $\%$ & \\
\hline & $f$ & $\%$ & $\mathrm{~F}$ & $\%$ & & & \\
\hline $\begin{array}{l}\text { 46-55 Early elderly } \\
\text { Economic status }\end{array}$ & 6 & 24,0 & 19 & 76,0 & 25 & 100,0 & \\
\hline $\begin{array}{l}\text { Less than minimum } \\
\text { regional wage }\end{array}$ & 9 & 36,0 & 16 & 64,0 & 25 & 100,0 & 0,278 \\
\hline $\begin{array}{l}\text { More than minimum } \\
\text { regional wage }\end{array}$ & 7 & 20,0 & 28 & 80,0 & 35 & 100,0 & \\
\hline \multicolumn{8}{|l|}{ Education level } \\
\hline High school & 9 & 22,5 & 31 & 77,5 & 40 & 100,0 & 0,470 \\
\hline Higher education & 7 & 35,0 & 13 & 65,0 & 20 & 100,0 & \\
\hline \multicolumn{8}{|l|}{ Family support } \\
\hline Poor & 1 & 5,0 & 19 & 95,0 & 20 & 100,0 & 0,011 \\
\hline Good & 15 & 37,5 & 25 & 62,5 & 40 & 100,0 & \\
\hline Total & & & & & 60 & 100,0 & \\
\hline
\end{tabular}

Based on Table 2, it showed that there was no relationship between age and mothers coping strategies with $\mathrm{p}=0.921(\mathrm{p}>0.05)$. There was no relationship between economic status and mothers coping strategies because the test results showed $p=0.278(p>0.05)$. There was no relationship between education level with mothers coping strategy because the test results showed $p=0.470$ $(\mathrm{p}>0.05)$. There was a relationship between family support and mothers coping strategies because the test results showed $\mathrm{p}=0.011(\mathrm{p}<0.05)$.

\section{DISCUSSION}

\section{A. Relationship between age and coping strategies of} mothers who had autistic children

The results showed that of $35(58.3 \%)$ respondents aged 36-45 years, there were $25(41.7 \%)$ respondents who had good strategies and there were $10 \quad(28.6 \%)$ respondents who had poor coping strategies while 25 $(27.4 \%)$ of respondents aged 46-55 years there were 19 (76.0\%) of respondents who had good coping strategies and there were $6(24.0 \%)$ of respondents who had poor coping strategies.It was known that there was no relationship between age and mothers coping strategies because the Chi Square test results showed $\mathrm{p}=0.921(\mathrm{p}>$ 0.05 ). Thus, there was no relationship between age and coping strategies because each respondent has its own stress level and late adulthood experienced more stress in work situation, social relations with friends compared to the elderly who were mostly not working and the age of most mothers who have autistic children was late adulthood.

This finding strengthens the research of [12] Statistical test results using Pearson Chi Square obtained $\mathrm{p}$ value $=0.332>0.05$ which indicated there was no relationship between age and mothers depression level. This can be caused by the ability of stress coping that is different for each person. It is known that in middle age individuals experience more stress related to work, finance, family, and friends. The coping that leads to direct action is made possible by more effective coping strategies against various stressors faced by individuals. The study conducted by Pratiwi and Dundu was almost the same as the results of our study because there was no relationship with age coping strategies [12]. Research in 2010 by Pisula and Kossakowska explains that parents of children with autism the sense of coherence (SOC) level was positively associated with seeking social support and self-controlling, and negatively with accepting responsibility and positive reappraisal [13].

B. Relationship of economic status with coping strategies of mothers who had autistic children 
The results showed that of the $25(41.7 \%)$ respondents whose income economic status was less than the minimum regional wage there were 16 (64.0\%) respondents who had good coping strategies and there were $9(36.0 \%)$ respondents who had poor coping strategies. While, $35(58.3 \%)$ of respondents whose income economic status was more than minimum regional wage there were $28(80.0 \%)$ respondents who had good coping strategies and $7(20.0 \%)$ respondents who had poor coping strategies. It was known that there was no relationship between economic status with coping strategies of respondents because the Chi Square test results showed $\mathrm{p}=0.278$ and multivariate results 0.111 ( $p>0.05$ ). There was no relationship between economic status with coping strategies because mothers will try their best to cure their children despite had to spend money. Mothers also had support from families to meet the needs of mothers and children so that there was no problem with economic status. As increasing the cost of living, parents who had children with autism had to pay more, but the community was also tackling this increase in costs. If multiplied by the number of individuals affected, then this was a very large cost for just health care [14]. That one of the factors affecting coping was socioeconomic status, individuals who had low socioeconomic status were more often negatively affected by stress so they were familiar with crime, mental illness, and alcoholic drinks.

\section{Relationship of education level with coping strategies of mothers who had autistic children}

The results showed that of the $40(66.7 \%)$ respondents who had a high school level of education there were 31 (77.5\%) respondents that had good coping strategies and there were $9(22.5 \%)$ respondents who had poor coping strategies while $20(33.3 \%)$. Meanwhile, mothers who had diploma/academy/ higher education level that had good coping strategies were $13(65.0 \%)$ respondents and there were $7(35.0 \%)$ respondents who had poor coping strategies. It was known that there was no relationship between education level with mothers coping strategies because the Chi Square test results showed $p=0.470(p>$ 0.05 ). There was no relationship between education with coping strategies because the era was increasingly sophisticated and everyone can get information from handphone, the internet, books, friends, family and so forth.

This is inversely proportional to study conducted [8]. The level of education will greatly affect the cognitive complexity of individuals to deal with a pressure. According to [9] the level of education can affect one's coping strategies because the higher level of education means the easier it is for someone to receive health information. Someone who has a background of a lower educational level develop attitude and the process of maturity has not been able to because of experience and level of knowledge. There was no relationship between education with coping strategies because the times are increasingly sophisticated and everyone can get information from handphone, the internet, books, friends and so forth.

\section{Relationship of family support with coping strategies of mothers who had autistic children}

The results showed that of the $20(33.3 \%)$ respondents who had poor family support who had a good coping strategy there were $19(95.0 \%)$ respondents and respondents but had poor family support who had a bad coping strategy there were $1(5.0 \%)$ respondents. While, $40(66.7 \%)$ respondents who had good family support who had a good coping strategy there were 25 (62.5\%) respondents and respondents who had good family support but who had a poor coping strategy there were 15 $(37.5 \%)$ respondents. There was a relationship between family support and coping strategies because the Chi Square test results showed $\mathrm{p}=0.011$ and multivariate results 0.019 ( $p<0.05)$, the most widely used family support by mothers who had autid children in Arogya Mitra Acupuncture Klaten, the first was emotional support with a mean of 140.80 . The second was assessment support with a mean 140.00 . The third was instrument support with a mean of 139.25. The fourth was information support with a mean 137.60. Family support was very meaningful for respondents who had autistic children the higher the family support the respondent will be more calm and stronger in caring for their children. Parents of children with autism experienced more stress and used planning as a coping strategy to a greater degree than parents of children with other developmental disabilities [15].

Research consistently shows that social support plays an important role in reducing parenting stress and increasing mothers psychological well-being [8]. Support and attention from the family as well as from the environment so that makes mothers who had autistic children feel stronger, patient and enthusiastic in caring for children with autism. In accordance with our study that family support was very meaningful for respondents who had autistic children the higher the family support the respondent will be more calm and stronger in caring for their children. These parents do not receive the same kind of "reinforcement" from parenting their child compared to aparent with a child with DS or a typically developing child. Many of these parents deal with very difficult behaviors, have no way of functionally communicating with their child, and are not able to interact socially with their child [16]. Parents of children with ASD experienced significantly more parenting stress and depression symptoms, and engaged in more maladaptive coping, than parents of typically developing children. While parenting stress effects were consistently observed among different groups of parents in this study, parental coping on the other hand could be sensitive to cultural influences or caregiving demands from the environment [17].

\section{CONCLUSION}

The results of the analysis of the risk factors affecting the coping strategy of mothers who have children with 
autism in Arogya Mitra Acupuncture Klaten can be concluded that influence coping strategies namely family support, meanwhile others risk factors do not affect coping strategies namely age, education level, economic status.

\section{REFERENCES}

[1] R. Kemenpppa, "Hari Peduli Autisme Sedunia: Kenali Gejalanya, Pahami Keadaannya,” 2018.

[2] R. Rahmania, N. Nurwati, and B. M. Taftazani, "Strategi Koping Ibu Dengan Anak Gangguan Spektrum Autisme: (Studi Kasus: Orangtua Murid Taman Kanan-Kanak Mutiara Bunda)," Pros. Penelitian dan Pengabdian Kepada Masyarakat., vol. 3, no. 3, p. 334, 2016.

[3] WHO, “Autisme," 2016.

[4] R. Kemenkes, "Kenali Dan Deteksi Dini Individu Dengan Spektrum Autisme Melalui Pendekatan Keluarga Untuk Tingkatkan Kualitas Hidupnya,” 2016.

[5] Muhith, Pendidikan Keperawatan Jiwa. Yogyakarta: CV. Andi Offset, 2015.

[6] J. K. Gona et al., "Challenges and coping strategies of parents of children with autism on the Kenyan coast," Rural Remote Health, vol. 16 , no. 2 , pp. 1-13, 2016

[7] N. A. Fitriyaningrum and S. Hindriyastuti, "Prosiding Hefa ( Health Events for All )," Hub. Dukungan Kel. Dengan Kemandirian Oral Hyg. Anak Tuna Grahitadi Sekol. Luar Biasa Negeri Kaliwungu Kudus, vol. PROSIDING, pp. 89-100, 2018.

[8] Z. N. C. Nisa, "Strategi Coping Orang Tua Yang Memiliki Anak Autis, ” p. 200, 2017.

[9] A. Ma'rifah, N. P. Suryantini, and R. Mardiyana, "In Reply: Behaviour Therapy," Br. J. Psychiatry, vol. 112, no. 483, pp. 211212, 2018.

[10] D. Astuti, Abrori, and O. Widyastutik, "Hubungan Strategi Koping dengan Stress Pada Ibu Dengan Anak Autis Di Autis Center Kota Pontianak, " 2018.

[11] S. Notoatmodjo, Pengantar ilmu pedidikan dan ilmu perilaku kesehatan. Jakarta: Rineka Cipta, 2012.

[12] D. S. Pratiwi, A. E. Dundu, and B. H. R. Kairupan, "Analisis Faktor- Faktor yang Memengaruhi Depresi pada Ibu Kandung yang Memiliki Anak dengan Retardasi Mental di Sekolah Luar Biasa Yayasan Pembinaan Anak Cacat Manado," e-CliniC, vol. 6, no. 1, pp. 1-7, 2018.

[13] E. Pisula and Z. Kossakowska, "Sense of coherence and coping with stress among mothers and fathers of children with autism," J. Autism Dev. Disord., vol. 40, no. 12, pp. 1485-1494, 2010.

[14] D. H. Pebrianto, "Strategi Koping Orangtua Pada Anak Dengan Retradasi Mental Di Sekolah Luar Biasa C/CI Shanti Yoga Klaten," 2015.

[15] P. Wang, C. A. Michaels, and M. S. Day, "Stresses and Coping Strategies of Chinese Families with Children with Autism and Other Developmental Disabilities," J. Autism Dev. Disord. pp. 783-795, 2011

[16] S. Siklos and K. A. Kerns, "Assessing need for social support in parents of children with autism and Down syndrome," J. Autism Dev. Disord., vol. 36, no. 7, pp. 921-933, 2006.

[17] W. W. Lai, T. J. Goh, T. P. S. Oei, and M. Sung, "Coping and Well-Being in Parents of Children with Autism Spectrum Disorders (ASD)," J. Autism Dev. Disord., vol. 45, no. 8, pp. 2582-2593, 2015. 